\title{
1990年フィリピン地震の地震断層
}

\author{
中 田 高* 堤 浩 之 之* $^{*}$ Raymundo S. PunONGBAYAN ${ }^{* * *}$ \\ Rolly E. RIMANDO ${ }^{* * *}$ Jessie DALIGDIG ${ }^{* * *}$ Arturo DAAG ${ }^{* * *}$
}

\section{Surface Faulting Associated with the Philippine Earthquake of 1990}

Takashi NAKATA*, Hiroyuki TSUTSUmi ${ }^{* *}$, Raymundo S. PUNONGBAYAN ${ }^{* * *}$, Rolly E. RIMANDo ${ }^{* * *}$, Jessie DALIGDIG ${ }^{* * *}$ and Arturo DAAG ${ }^{* * *}$

\begin{abstract}
The Philippine Earthquake ( $\mathrm{Ms}=7.8$ ) broke out in July 16, 1990 along the Philippine Fault in Central Luzon. The Philippine Fault is seismically very active and large earthquakes of M 7 class have occurred during this century along this fault. However large earthquakes have not taken place along the active traces of the fault in the Central Luzon during this century, while two large historical earthquakes occurred along its southern trace in 1645 and its northern trace in 1796. Therefore it is considered that the 1990 earthquake was caused by the surface faulting in the seismic (aseismic) gap along the Philippine Fault.

The total length of the surface fault is over $120 \mathrm{~km}$ and the fault is divided into two segments by the major bend near Rizal. The surface fault is rather straight and linear and general orientation of the northern segment is $\mathrm{N} 25 \mathrm{~W}$ and the southern segment $\mathrm{N} 40 \mathrm{~W}$. Left-lateral displacement is dominant along most of the fault traces and the maximum horizontal displacement is about $6 \mathrm{~m}$ in the $60-\mathrm{km}$-long northern segment and the maximum vertical displacement is $2.0 \mathrm{~m}$ in the $50-\mathrm{km}$-long southern section. Sense of vertical displacement changes in places and is consistent with the sense of the displacement along the pre-existing active fault traces. Average displacement along the northern segment is 5-6 $\mathrm{m}$, while 2-3 $\mathrm{m}$ along the southern segment.

Along most of the surface fault, ruptures appear exactly along the pre-existing active fault traces. Offsets of roads, foot-pass, streams are common earthquake-induced features. Local extensional and compressional jog forms related to slight change in fault strike creates characteristic features such as depressions, trenches, mole tracks, bulges etc.

The rupture propagated bilaterally northward and southward from hypocenter east of Bongabon near the major bend. The source process of the earthquake deduced from the slip distribution along the surface fault from the epicenter well coincides with that deduced seismologically from the source time function.
\end{abstract}

\footnotetext{
* 広島大学文学部地理学教室 *Department of Geography, Hiroshima University

** 広島大学大学院 ${ }^{* *}$ Graduate tudent, Hiroshima University

***フィリピン火山地震研究所 ${ }^{* * * P h i l i p p i n e ~ I n s t i t u t e ~ o f ~ V o l c a n o l o g y ~ a n d ~ S e i s m o l o g y ~}$ 


\section{I. はじめに}

1990年 7 月16日にフィリピン・ルソン島中部で発生した大地震は, 既存のフィリピン断層系 (ALLEN, 1962，1975)の一部の再活動によって発生した(図 1 )。震源地域では地震に伴って顕著な地震断層が地表に 出現し,私たちの調査によって確認されたものでも長さ約 $120 \mathrm{~km}$, 最大变位量 $6 \mathrm{~m}$ 近くに達するきわめて大 規模なものであることが明らかとなった。地震の 2 週間後, 約 10 日間にわたって地震断風の分布と变位量の 調査を実施した。短期間であったため十分な調査ができなかったらえ, 各地で橋が破壊され，崖崩れや洪水 によって道路が不通となっており,いまたに現地に入ることが難しい地域もある。このため, 地震断層の全 区間を踏査することはできなかったが,へリコプターからの観察を加え，地震断層の特徽について報告する。

\section{II. 地震と地震断層の概要}

今回の地震はアメリカ地質調査所 (USGS) によって1990年 7 月 16 日07時26分 34.4 秒 (グリニッジ標準時 一一現地夏時間午後 4 時 26 分 34.4 秒) に発生し, マグニチュードは7.8, 震央はボンガボン (Bongabon) の東約 $10 \mathrm{~km}$ の北緯 15.658 度, 東経 121.227 度にあり, 震源の深さは $25 \mathrm{~km}$ とされた。この震央は, 地震 に伴って現われた断層の東 $6 \sim 7 \mathrm{~km}$ に位置している。この地震の死傷者は主に山崩れと高層建物の倒壊に よるもので, その数は 3,000 人を超えるといわれている。リンガヤン（Lingayan） 湾に面した沖積平野では 広範囲にわたって液状化が起こり, 建築物に甚大な被害が発生した。

フィリピン断層はルソン島からミ ンダナオ島をで $1,200 \mathrm{~km}$ 以上にわ たってフィリピン群島を北西一南東 に緥断するきわめて活動度の高い活 断層である。今世紀に入ってもこの 断層に沿ってマグニチュード7クラ スの大地震が数多く発生してきたが (ACHARYA, 1980), ルソン島中部 のフィリピン断層に沿っては大地震 が発生していなかった。今世紀以前 には, ルソン島中部でもフィリピン 断層を震源とする大地震が1645年に 南部で，1796年に北部で記録されて いた（REPETTI, 1946 ; SEASEE, 1985)。この 2 つの地震発生域に挾 まれた地域は長期的に見てもいわゆ る地震の空白域になっており, 今回 の地震はこの空白域に位置していた ディグディグ (Digdig) 断層の活動 によって発生した。

\section{III. 地震断層の位置と変位量}

今回の地震によって発生した地震 断㬝は地表を破断する新鮮な割れ目

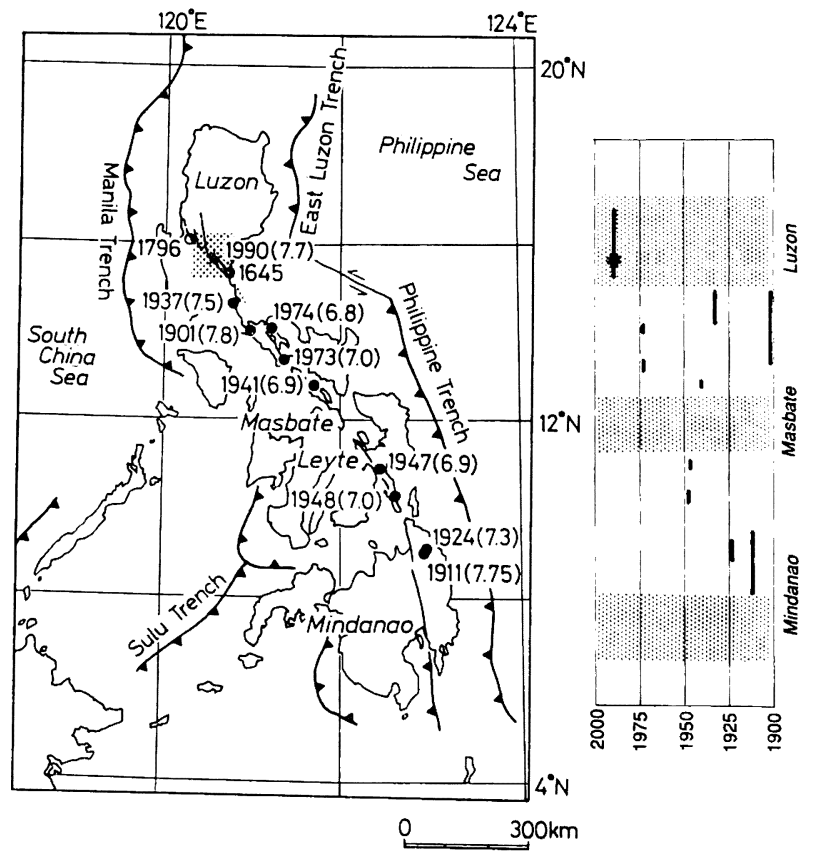

図 1 フィリピン断層に沿う今世紀の大地震

左図：フィリピン断層に沿う今世紀の大地霞の震央分布 Luzon 島中部には1645年, 1796年地震の震央と 1990 年地震 の震央を示す。アミは図 2 の範囲。

右図：地震の time-space ダイアグラム 太い実線は BONILlA et al. (1984) のマグニチュードと断 層の長さの関係式にしたがって求めた断層規模。アミは1990 年地震以前の地震空白域。 


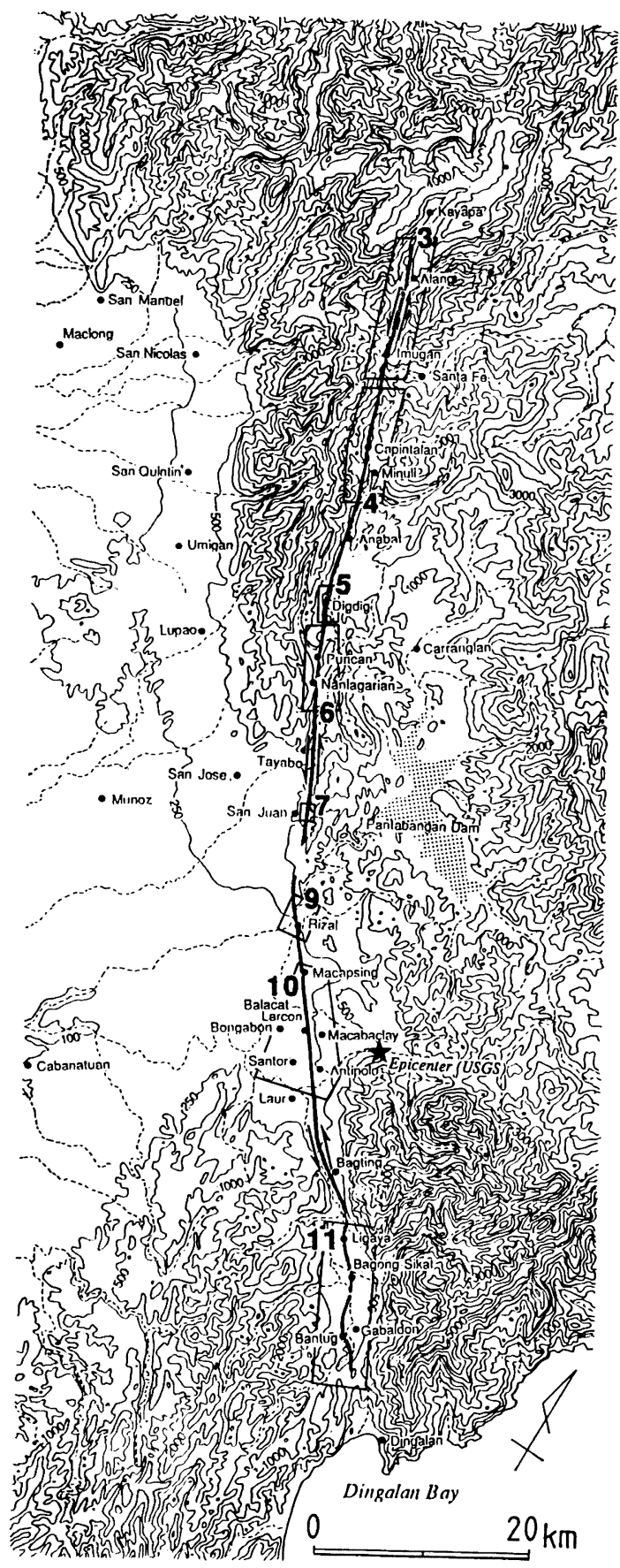

図 2 1990年地震の地震断層線の概略 断層線に沿う枠は図 3 以下の範囲。星印はUSGS

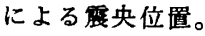

として追跡され, 道路, 小径, 水路, 畦, フェ ンスなどの食い違いなどから断層変位の様式と 量を知ることができる。断層帯は概ね幅 $2 \mathrm{~m}$ 前 後であり, この中にテンションクラック（tension crack）や凹地，モールトラック（mole track）状の膨らみなどの微地形が発達する。 テンションクラックやモールトラックはミの字 状の配列 (right-step echelon) を呈している。 また，主断層に平行あるいは斜交する副次的な 断層の発達が認められる場所もある。

地震断層の観察から, 今回の地震を発生させ た断層運動は, 左横ずれ変位成分が卓越するも のであることが確認された。これは，既存の活 断層から推定される変位様式および今回の地震 の発震機構（阿部・吉田, 1990）と調和する。 縦ずれ変位のセンスは地域的に変化するが，こ れも既存の活断層の縦ずれ変位センスと調和的 である場合が多い。しかし，局地的には横ずれ 変位に伴ら見かけ上のものである場合もある。

地震に伴って地表に現われた断層線は, 図 2 に示すよらにヌェバビスカヤ(Nueva Vizcaya) 州サンタフェ（Santa $\mathrm{Fe}$ ）の西に位置するイ ムガン (Imugan) の北方約 $20 \mathrm{~km}$ の尾根上に 出現し, ナシフーン (Nasiaan) 川に沿って南 に延び，イムガンの集落を破壊しヌェバェシハ (Nueva Ecija) 州に入る。ほぼディグディグ 川の流路に沿ってキャピンタラン (Capintalan) から南に直線的に延びディグディグに達し，プ ンカン (Puncan) を経てタラベラ（Talavera） 川にそってタヤボ (Tayabo) の東の山麓に至 る。そこからマンゲオバン (Mangeoban) 山 地の直線的な西麓に沿ってサンジュアン（San Juan）の東に延びる。断層線はディグディグ 付近から北に向かって多少走向を北よりに変化 するが，この区間での一般走向は N25W で概 ね直線的である。

サンジュアンとリサール（Rizal） との間に は, 地震断層が発達しないギ+プがある。リサ ールから南では地震断層の一般走向は N40W と変化し，パンパンガ (Panpanga) 川の左岸 のマカプシン (Macapsing) で集落と水田を変 位させ, ディグラ（Digmala）川の扇状地 
を横切ってボンガボンの東 に達し、さらにコロネル (Coronel) 川の右岸に沿 ってバグティン (Bagting) の南に至る。ガバルドン (Gabaldon) 盆地に入り, 盆地のほぼ中央部を屈曲し ながら水田を横切って, 南 西のバントゥク (Bantug) の南に至り, ディンガラン (Dingalan) の北の峠で消 滅する。

地震断層の位置や変位量 を中心に地域毎にやや詳し く記载する。地震断層位置 図には，現地調査によって 計測した断層変位量をイタ リック数字で示す。これら は断層変位の相対的隆起側 にメートル単位で記され， 左側の数値が横ずれ量, 右 側の数值が上下量を示す。 ?は計測不能あるいは未計 測を意味する。狭い範团で 変位量が大きく変化する地 域もあるが，採用した数值 はそれぞれの地域を代表す ると考えられるものであ る。実変位量 (net slip) は，横ずれ変位量と上下変 位量, および水平短縮／伸 張量の合成值で求められる が，水平短縮／伸張量を計 測することができない場合 が多く，正確な值を求める

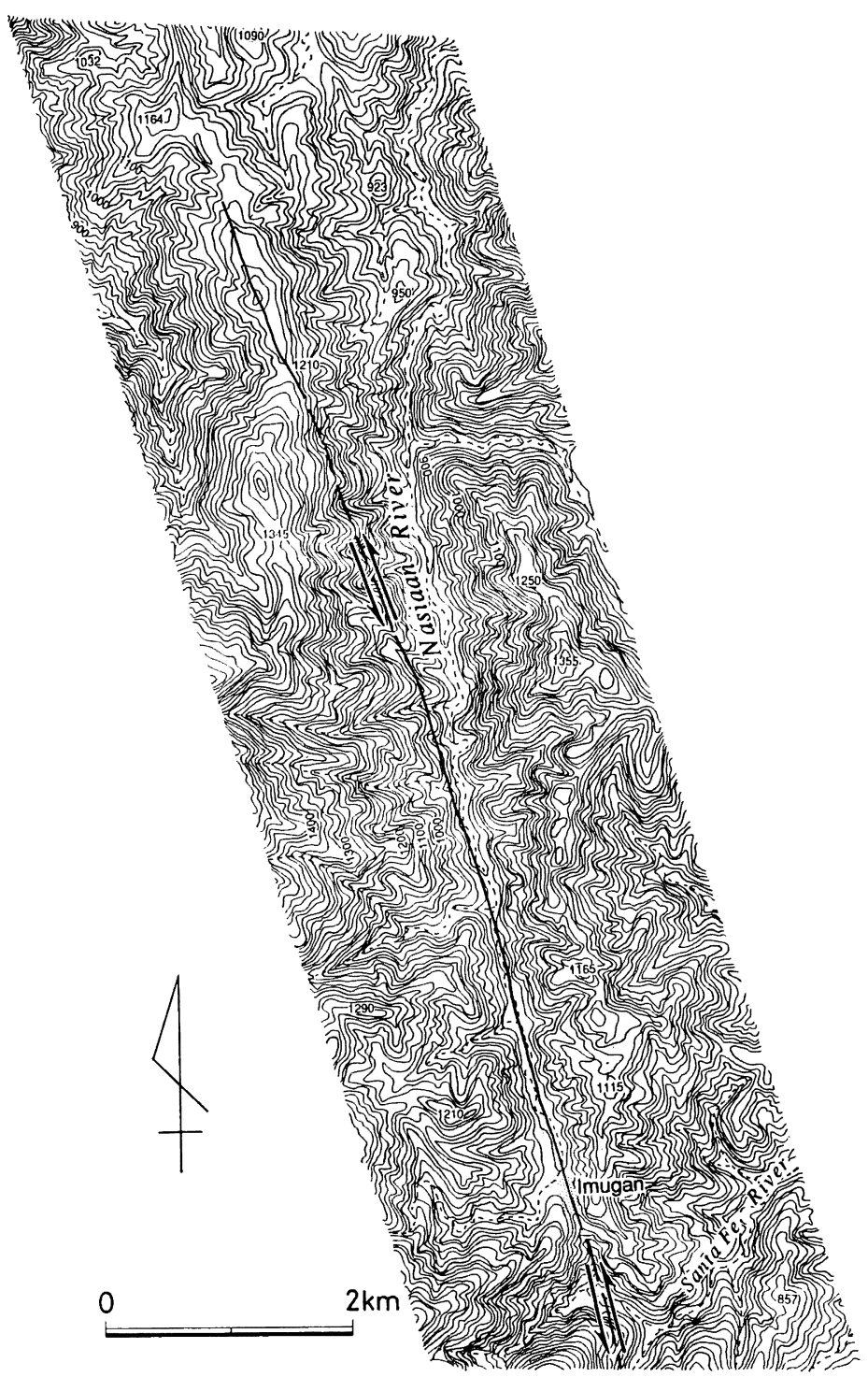

図 3 Imugan 北方における地震断層線 (ヘリコプターからの観察に基つく） ことは困難である。

1）イムガンより北の区間（図 3)

今回の調査で確認された地震断層の最北端は, イムガンの北約 $20 \mathrm{~km}$ の南北方向の断層谷の谷頭部に出 現する。これより南では断層線はN30Wの一般走向を示し, 南北方向の平頂尾根のほぼ中央部に幅 2-10m にわたって何本かのミの字状の雁行配列を示す引張割れ目を形成し，北に向かって枝状に分岐している(口 絵写真 1 )。断層線は $1,210 \mathrm{~m}$ 付近の鞍部から, N20W の走向で南に向かってナシアーン川の谷壁を斜めに 横切って幅広い谷底に達する。この谷はイムガンの集落の南方において, 上流部がサンタフェ川の支谷によ 


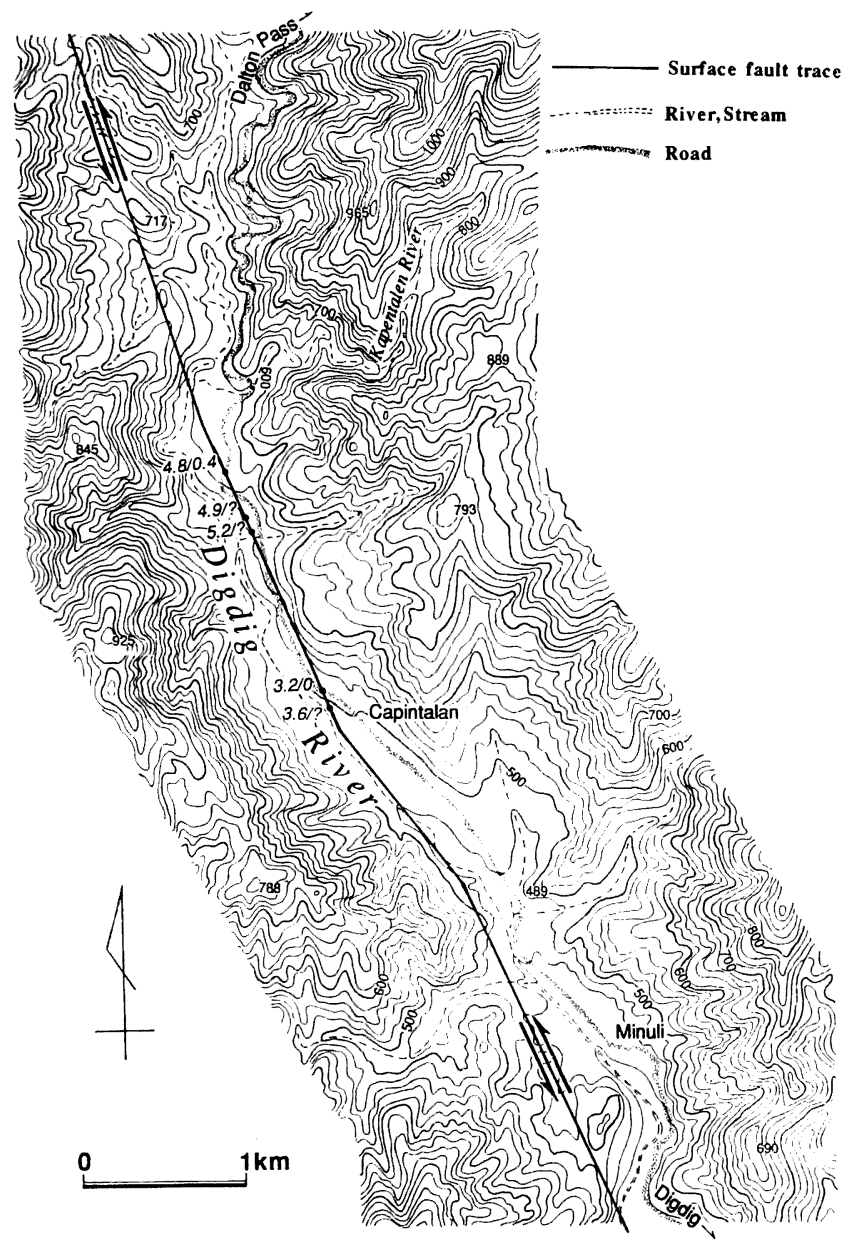

図 4 Capintalan 周辺の地震断層と変位量

変位量を示す斜め数字は左が横ずれ量 $(\mathrm{m})$, 右は上下変位量 $(\mathrm{m})$ 。? は計測不能あるいは未計測を意味する。数字は相対的な 隆起側に記入してある。
って争雀されたために，流路に 比べ幅広い谷底となって扣り， 水田として利用されている。地 震断層はこの谷底平野のほぼ中 央を $\mathrm{N} 15 \mathrm{~W}$ の走向で直線的に南 に延び，これらの水田の畦を連 続的に左横ずれさせている（口 絵写真 2 )。写真を細かく観察 すると，断層線に沿って地畕状 の細長い高まりや，溝状の凹地 が交互に発達していることがわ かる。すなわち，断層線の方向 が一般方向よりわずかに北に屈 曲する場所では圧縮の場が，西 に屈曲する場所では引張の場が 局地的に形成されており， それらが断層線上の小規模な Restraining Bend と Releasing Bend (SIBSON, 1986) にあたることがわかる。地震断 層は, 河川争奪の肘の場所に立 地するイムガンの集落を縦断す る。道路の食い違いから左横ず れ6.1m，東上がり $0.5 \mathrm{~m}$ の最大 変位が認められ，断層線上に位 置する建物はことごとく破壊さ れた。

2) キャピンタラン周辺（図 4)

イムガンの南で地震断層は, サンタフェ川上流の支谷やディ

グディグ川右岸の支谷や尾根を横ずれ変位させ， N20Wの走向で南に延び，ディグディグ川の本流を横切 り左岸に達し, キャピンタランの集落の北に至る。ここで, 国道 5 号線を初めて横切り, コンクリート舗 装の道路を左ずれ $4.8 \mathrm{~m}$ ，西上がり $0.4 \mathrm{~m}$ 変位させる。これから南で再びディグディグ川の沖積面に達した 地震断層は, 畑の畔や小径を左に $4.9 \mathrm{~m}, 5.2 \mathrm{~m}$ 横ずれさせ, さらに南で国道を鋭角に横切る。このため, 地震断層と共役角に近い方向にあるコンクリート舗装の継目に沿って，右横ずれ変位が生じている。谷壁 の中腹を切って直線的に南に続く断層が再び国道を横切る場所では，コンクリート舗装が $3.2 \mathrm{~m}$ 左横ずれ すると共に水平短縮を起こし，尾根形にめくれ上がっている（口絵写真 3 ）。コンクリート部分の重なり具 合いから，短縮量が $1 \mathrm{~m}$ 以上であることがわかる。コンクリートの破断面には西上がり 5 度の条線が残さ れている。断層線は既存のプレッシャーリッジ（pressure ridge）の東側基部の南方延長線上に位置してお り,このプレッシャーリッジをさらに成長させるように断層変位が起こったことがわかる。簡易測量の結 果から断層を挾んた上下変位は認められず，断層の北西部の幅約 $50 \mathrm{~m}$ の部分が撓み上がっていることがわ 
かった。よって，このよらな変形は広範囲には拉よんでいない。これより南では,ディグディグ川の左岸 の人工水路の食い違いから， $3.6 \mathrm{~m}$ の横ずれ変位が認められる。さらに南の川沿いの低地では, 地震直後 に撮影された空中写真で認められた断層線が，その後の洪水によって調査時には消失しており，変位量を 明らかにすることができなかった。地震断層はキャピンタランの南約 $1 \mathrm{~km}$ の地点からディグディグ川の 右岸に至り南に続くが，洪水によって渡河することができず変位量は不明である。キャピンタランとミニ ニリ（Minuli）との間の地震断層の走向は変化し，これより南では N25W の走向を示す。ミニュリの対 岸で, 断層線が支谷の合流扇状地を 横切る場所でも，水田の畦が連続的 に食い違っているのが認められる。 さらに南のアナバット (Anabat) の対岸の支谷が本流の上流方向に系 統的に屈曲する場所では, 地震断層 は屈曲部を連ねる位置に出現してお り, このような屈曲が地震時の左ず れ变位の累積によるものであること を裏付けている。

3）ディグディグ周辺（図 5)

地震断層の走向は，大局的に見る とディグディグ付近でN25WからN 35W に“く”の字状に变化し, ディ グディグより北が圧縮の場にあたっ ていると考えられる。ディグディグ の北約 $1.5 \mathrm{~km}$ のマンガハム (Caamanggaham）では国道が水平的にず れ， $4.4 \mathrm{~m}$ の左横ずれが認められ る。その南では断層線は既存のプレ ッシャーリッジの東の基部に沿って 出現しており, 変位量は定かではな いが垂直的には西側が隆起する。プ レッシャーリッジの南では断層線は 既存の断層回地（fault sag）の直線 的な西縁に沿って走り,プロ (Pulo) での変位は国道の食い違いから左横 ずれ $5.6 \mathrm{~m}$ ，西上がり $0.3 \mathrm{~m}$ である ことがわかる。道路脇の家屋は断層 上に位置していたものだけが著しく 破壊され，周辺の家屋には被害がほ とんど出ていない（口絵写真 4 )。プ 口南の河岸段丘上の小径のずれか ら，4.2mの左横ずれが認められる。 プロとディグディグのほぼ中間で, 地震断層は局地的に走向を $\mathrm{N} 45 \mathrm{~W} に$

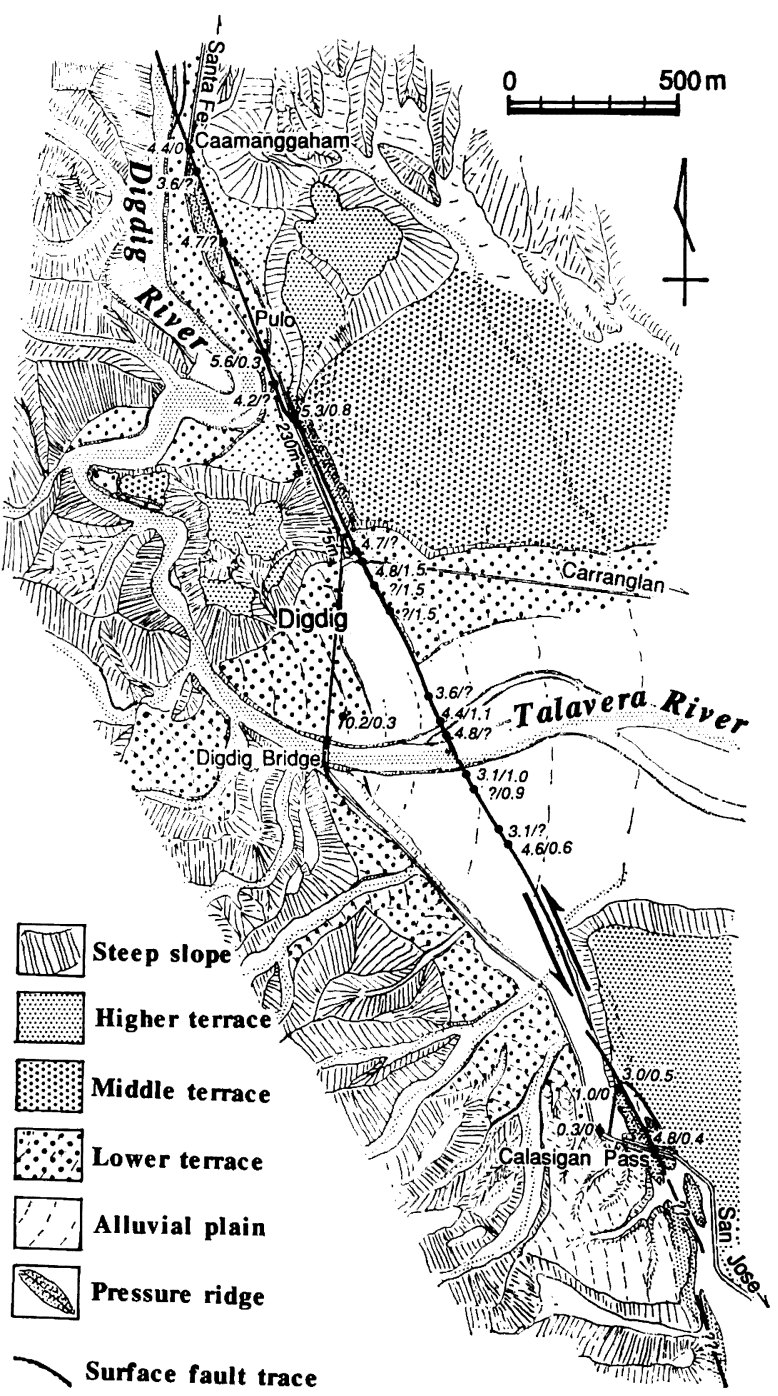

図 5 Digdig 周辺の地震断層と変位量 変位量を示す斜め数字は左が横ずれ量 $(\mathrm{m})$ ，右は繸ずれ量 $(\mathrm{m})$ 。?は計測不能あるいは未計測を意味する．数字は相対 的な隆起側に記入してある。断層線に平行して記された数字 は段丘崖の横ずれ累積変位量。 
変え国道を横切るが，そこでは引張場が形成され道路が引き裂かれた様子を示す。ここでの左横ずれは $5.3 \mathrm{~m}$ となり, 上下変位成分は西上がりから東上がりに变化し，その量は $0.8 \mathrm{~m}$ である。断層線は道路の東 で走向が $\mathrm{N} 20 \mathrm{~W}$ となり, 中位段丘を横切って形成されたプレッシャーリッジの西縁に沿って南へ続く。プ レッシャーリッジの西は切り通し状の直線的な凹地となっており，この部分を国道が通っている。プレッ シャーリッジの南端付近で国道は南へ曲がるが，地震断層は低位段丘を切って形成された既存の西向きの 低断層崖の中腹に沿って直線的に延びる。ディグディグの周辺は，各種の活断層地形の保存がよい地域 で, 今回の地震でも見事な地震断層が出現した（口絵写真 5 )。中位段丘と低位段丘の間の段丘崖の基部か ら約 $50 \mathrm{~m}$ ほど南南東に行ったところにあるポンプは，地震前には民家の勝手口の前にあったものが左横ず れ変位し, 元の位置より北の方へ $4.7 \mathrm{~m}$ 相対的に移動した。地震断層は, ディグディグの国道三叉路から カラングラン (Carranglan) 道路を東へ約 $40 \mathrm{~m}$ 行ったところでこの道路を横切り, 左横ずれ $4.8 \mathrm{~m}$, 東上が り $1.5 \mathrm{~m}$ の変位を生している（口絵写真6)。この道路の北で断層上にあったコンクリート造りの民家は，こ のような地盤の变位によって完全に破壊されだ。カラングラン道路より南でも，地震断層は既存の低断層 崖の中腹に沿って南南東に続く（口絵写真 5 )。地震前に比高 $3.5 \mathrm{~m}$ であった逆向き低断層崖（NAKATA et al., 1977) は, 今回の地震で $1.5 \mathrm{~m}$ その比高を増している。低断層崖の西にあった断層凹地には水が溜 ク, サグポンド (sag pond) 化している。地震断層は低断層崖の北半部では直線的な崖を呈せず，ミの字 状の引張割れ目となるが，この場所では地震断層の走向が局地的に一般走向からわずかに西に偏してい る。低断層崖の南半部では地震断層はシャープな小崖として認められる（口絵写真 5 ）。タラベラ川の左岸 では, 今回の地震前には変位の認められなかった沖積面や旧流路を横切っている。ここでは㹟い範囲で横 ずれ変位が $3.6 \mathrm{~m} \sim 4.8 \mathrm{~m}$ と変化するのが小径のずれより認められるが，野外ではしばしば断層変位の全体 のスリップ（slip）の量を求めることが困難であり，小さい計測值はその一部のオフセット（offset）の量 を示していると考兄れる。

タラペラ川を横切る部分では, 両岸が左横ずれを起こし下流側が相対的に隆起している様子が地震直後 の空中写真では認められるが，調査時にはすでに侵食されて残存していなかった。

タラベラ川の左岸では短い副次的な地震断層線が, 主断層から西へ $250 \mathrm{~m}$ 近く離れたディグディグ小学 校周辺でも現われている。コンクリートブロックの塀のずれなどから知られる変位量は, 左横ずれ $0.2 \mathrm{~m}$, 東上がり $0.3 \mathrm{~m}$ と小さいが, この地表変位の直撃を受けた小学校の校舎や民家は大きな被害を受けている。 ディグディグ三叉路の南西の小径では，北東一南西の走向をもつ副次的な断層によって，䡴が $0.3 \mathrm{~m}$ ほど 右横ずれしているのが認められた。

タラベラ川の右岸でも沖積面上の小径の左ずれから $3.1 \mathrm{~m} \sim 4.6 \mathrm{~m}$ の水平変位と, 東上がり $0.6 \mathrm{~m} \sim 1.0 \mathrm{~m}$ の上下変位が認められる。地震断層が 2 本のトレースに分㞳し, その間に幅 $10 \mathrm{~m} に$ 達するトレンチ (trench) が形成されるため, 正確な变位量を求めることには困難が伴う。トレンチが形成されている場所は地震断 層線が一般方向より北に向かって西偏し逆 “く”の字状に屈曲する北半部に位置し, 局地的な引張の場と なっている。

地震断層線は高位段丘を切る断層崖の基部に沿って南南東に向かって延びるが, カラシガン(Calasigan) 峠の北約 $400 \mathrm{~m}$ の地点で右雁行 (right-step echelon) にステップし, 段丘面上に向かって既存の断層崖を はい上がる。国道の旧道を地震断層が横切るところでは主断層線に沿って左横ずれ $3.0 \mathrm{~m}$, 東上がり $0.5 \mathrm{~m}$ 変位し, これから北西に枝別れした副断層線に沿って $1.0 \mathrm{~m}$ の左横ずれが認められる。地震断層は平行し て発達する 2 本のプレッシャーリッジの間を, 主断層とこれから北西に派生する右㕍行割れ目からなる幅 $10 \mathrm{~m}$ の広い断層帯をなして南に続く。プレッシャーリッジを横切ってつくられた国道の切り通しでは, 断 層線は再び 1 本となり, 切り通し道路を左横ずれ $4.8 \mathrm{~m}$, 東上がり $0.4 \mathrm{~m}$ 変位させている。カラシガン峠の 西約 $200 \mathrm{~m}$ の地点で南北方向の副次的な地震断層が国道を横切り, 道路を $0.3 \mathrm{~m}$ 左横ずれさせている。

ディグディグ周辺では，地震断層变位の累積を示寸地形学的な証拠がいくつか認められる（図 5 )。そ 
の一つは, 側方侵食崖の食い違いである。ディグディグ川の左岸, プロの南では中位段丘と低位段丘の中 間に発達する段丘面の背後の段丘崖が左ずれに約 $230 \mathrm{~m}$ 食い違っている。ディグディグでは, 低位段丘の 背後の段丘崖が約 $75 \mathrm{~m}$ 同梯な食い違いを見せている。低位段丘面上には, かつての河道の跡が明瞭に残存 して㧍り, 段丘面の年代は数千年と推定される。タラベラ川の左岸の高位・中位段丘は, その分布と形態 からタラベラ川が山地から盆地に出る谷口で形成されたものが, 現在の位置に断層運動の結果移動してき たものと考えることができる。それぞれの変位量は打拉よそ $1,000 \mathrm{~m}, 500 \mathrm{~m}$ と見積られる。同様に，カラ シガン峠の東に発達する高位段丘は，プンカン盆地に注ぐタラペラ川の支流によってタクタク（Taktak） より南において形成されたものが, 現在の位置に変位したと考兄られ, その変位量は $2 \mathrm{~km}$ 以上におよぶ と推定される(図6)。また, タラベラ川右岸の沖積面上の古い旧河道は地震断層に沿って $11.3 \mathrm{~m}$ 左横ず れしており，変位の累積性が認められる。

4）プンカン周辺（図6)

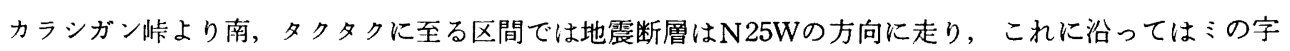
状雁行配列を示す短い断層線が発達している。いくつかの小経のずれから, 左横ずれ变位は概ね 4 〜 2 之 見積られるが, 断層線が $\mathrm{N} 35 \mathrm{~W}$ に屈曲する地点では横ずれ量が周辺より小さくなり, 東上がりの上下変位 量が多少大きくなる。プンカン橋の北東 $1.5 \mathrm{~km}$ の地点で地震断層が国道を横切るところでは, 横ずれ変 位量は $5.7 \mathrm{~m}$ と大きくなる。断層線は直線的に南南東に延び, 水田や河川を横切ってプンカンの集落に至 る。この間の変位量は, 田の畦, 牧場の柵, 民家のフェンスなどのずれから水平変位は $5 \mathrm{~m}$ 以上, 東上が りの垂直変位は $0.3 \mathrm{~m} \sim 0.9 \mathrm{~m}$ と見積られる。プンカンの集落の南では大規模なモールトラックが局地的に 発達している (口絵写真 7 )。水田の畦の食い違いから知られるここでの変位量は, 左横ずれ $4.6 \mathrm{~m}$, 東上 がり0.5mである。この南では, 断層線は “く”の字状にわずか走向を变え, 北では局地的な圧縮の場 が, 南では引張の場が形成されており, 断層線に沿って幅 $1.5 \mathrm{~m}$ にわたって引張割れ目が発達し, 浅い凹 地が形成されている。ここでは水田面と断層線に直交する民家の竹柵のずれから, 左横ずれ $5.0 \mathrm{~m}$, 東上 がり $0.7 \mathrm{~m}$ の変位が認められる。地震断層はこの南で山地斜面中腹の鞍部（notch）を通ってプンカン盆地 を抜け, ナンラガリアン (Nanlagarian) の北に達する。タラベラ川の支流にかかる国道の橋の東で, 地 震断層は支谷を横切り河道を $3.5 \mathrm{~m}$ 食い違わせ, この南で支谷の右岸の段丘上の畑に明瞭な直線的な低崖 を形成する。この断層線上に位置していた農家はこのため破壊を免れえなかった（口絵写真 8 )。ここで の断層変位量は, 畑の眭に植えられたバナナの列の食い違いから左横ずれ $4.8 \mathrm{~m}$, 東上がり $0.3 \mathrm{~m} \sim 0.7 \mathrm{~m}$ と計測される。ナンラガリアンの集落の北端から地震断層は屈曲する国道を何度か横切りナンラガリアン の南に至る。その北端の, 地震断層が道路をN $15 \mathrm{~W} て ゙$ 横切る所では, 左横ずれ $3.6 \mathrm{~m}$ が計測されるが, そ れより南では道路と低角で斜交するため変位量を求めることが難しい。ナンラガリアン橋の北でタラベラ 川の支谷を南に渡り, 谷の左岸に沿ってルンボィ (Lumboy) の北に至るが, この区間の地震断層の正確 な位置は不明である。

地震断層はルンボイの北で支谷の左岸の段丘上のトゥモロコシ畑を横切り, 畦道を左ずれ $3.6 \mathrm{~m}$, 東上 がり $0.3 \mathrm{~m}$ 変位させている。さらにタラベラ川本流右岸の段丘を横断し, $170 \mathrm{~m}$ 閉曲線の中央部に位置す るプレッシャーリッジの間を通り, 河岸に至る。地震断層はタラベラ川の左岸をN20Wの走向で南に延 び，タヤボ（Tayabo）の対岸で谷壁斜面の畑と雑木林との土地利用境界を $2.4 \mathrm{~m}$ 左横ずれさせる。

5) サンジュフン東方（図7）

タヤボからリサールにかけての直線的な断層崖の基部に沿って, 地震断層がN30Wの走向で現われた。断 層崖の基部には大小の扇状地か゚発達するが, 既存の活断層に沿ってこれらの扇状地や扇状地を開析する谷 に横ずれ変位が認められる。サンジュアンの東方では, 既存の活断層がパンタバンガンダム (Pantabangan Dam）に至る道路を横切る地点の周辺では, 扇状地を開析する水系に系統的な屈曲が認められる。高位扇 状地を形成した主谷が $130 \mathrm{~m}$, 扇央部を開析する谷も $80 \mathrm{~m}$ 左屈曲する。扇状地面自体の横ずれによって, 


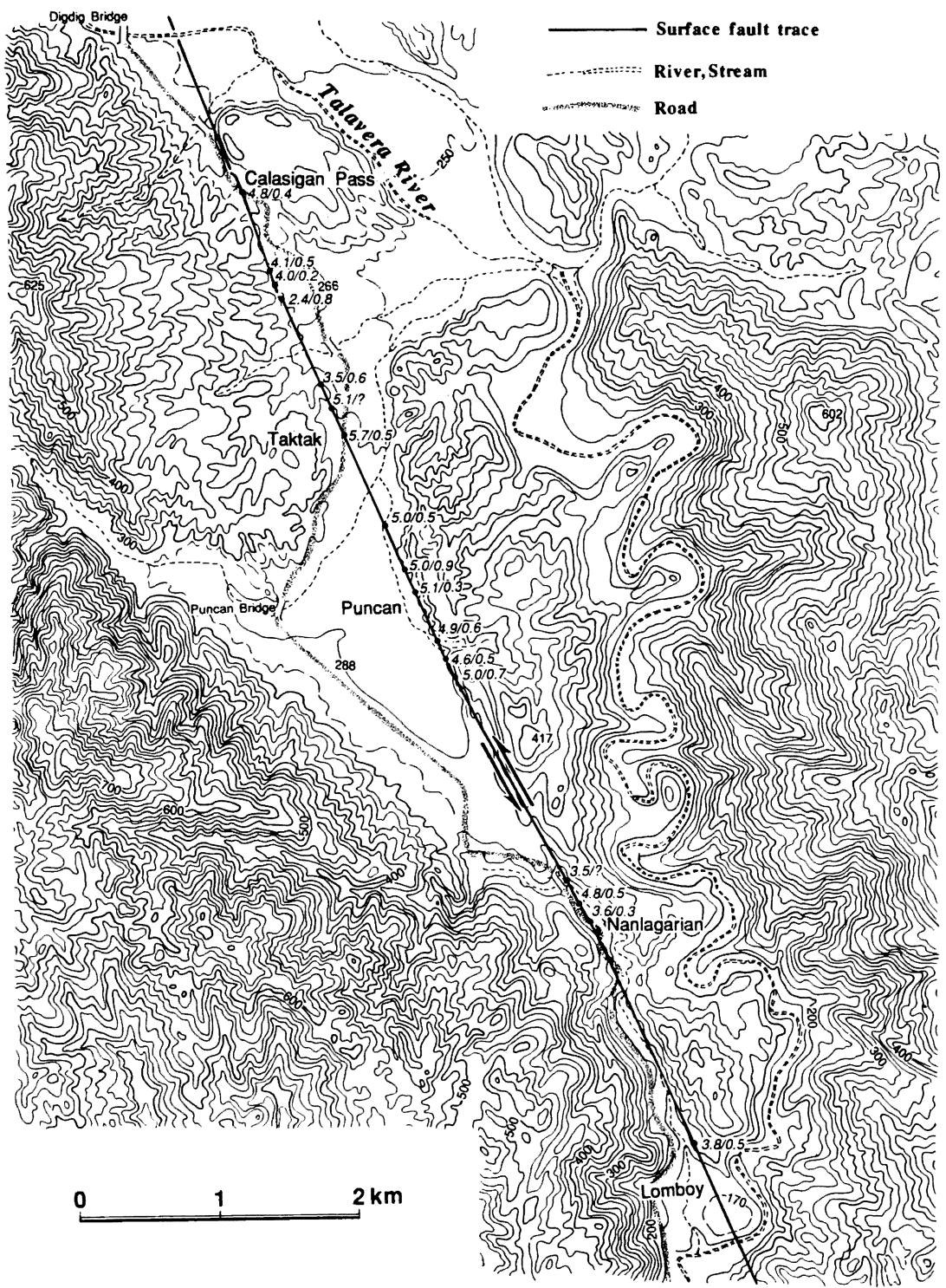

図 6 Calasigan Pass Lomboy の地震断層と変位量

変位量を示す斜め数字は左が横ずれ量 $(\mathrm{m})$ ，右は上下変位量 $(\mathrm{m})$ 。？は計測不能ある いは未計測を意味する。数字は相対的な隆起側に記入してある。

扇状地の南半部に東向きの逆向き低断層崖が発達している。地震断層はこの活断層地形に一致する位置に 出現し, その変位を增幅した。ヘンンタバンガンダム道路の南の屈曲部を曲流する流路を地震断層が何度か 横切り, $2.8 \mathrm{~m} \sim 3.6 \mathrm{~m}$ の横ずれ変位が生じた（図 8 )。

サンジュアンの東からリサールの北にかけては, 地震断層の変位量の急激な減少が認められ, 地震断層 はこの付近で大きく南北 2つのセグメントに分けられるかも知れない。

6) リサール周辺（因 9) 
リサールの周辺では, パンパンガ

川の右岸の河岸段丘群を切って発達 するN40W走向の直線的な顕著な断 層崖・低断層崖の基部に沿って，地 震断層の主断層が出現した。また， リサール市街の南東端から北に向か って分岐する副次的な断層楾が，市 街地を横切って現われた。

土断層線はリサールの北西約 $3 \mathrm{~km}$ にあるサンタフェリぺ（Santa Felipe）の集落の北東で，尾根や水系 の屈曲から推定される既存の活断層 のトレース上に現われ，小径を 0.5 m左横ずれさせるが，断層線はあま り顕著ではなく, 垂直変位は認めら

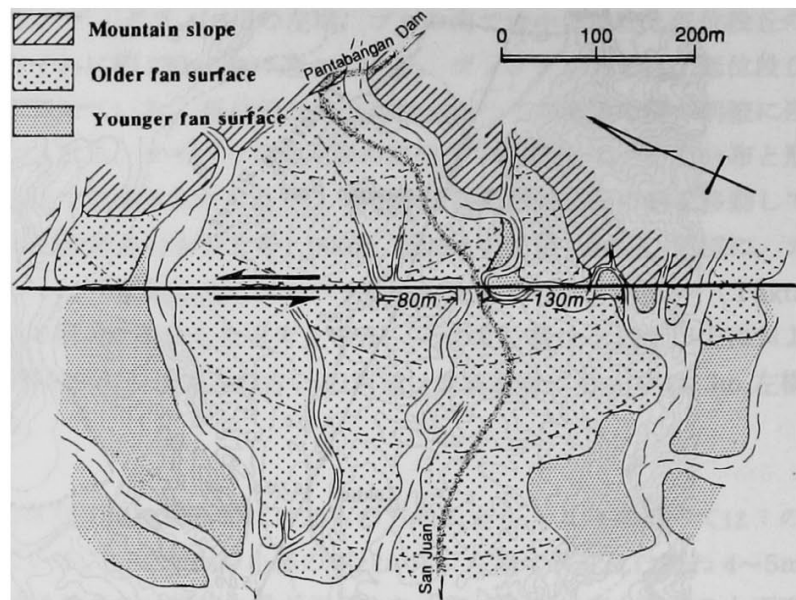

図 7 San Juan の東における stream offset

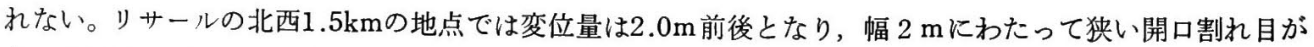
数本発達するが，ここでも上下変位は顕著ではない。リサールとサンホセ（San Jose）を結ぶ道路が低断 層崖と接する所では, 灌溉水路にかかる橋とその南東の道路の直下を地震断層が走ったため崩壊し, 破提部 から用水が水田に流入した。水路の南では, 墓地の南西の低断層崖の基部を地震断層が走り, 既存の低断層 からわずかに離れた沖積面に左ずれ $1.4 \mathrm{~m}$, 東上がり $0.1 \mathrm{~m}$ の変位を及ぽしている。地震断㬝は南の灌溉水 路の土手に幅 $5 \mathrm{~m} \sim 6 \mathrm{~m}$ にわたって無数の割れ目を生じて南東にこれを横切り, 水路に沿ってリサール市 街に達する。市街地では, 至るところで地震断層によって道路が食い違い, 断層上の家屋が破壊されている。 リサールとカバナトゥアン (Cabanatuan) を結ぶ主要道とその周辺では地震変位は, 左ずれ 2.2m 2.6 $\mathrm{m}$, 東上がり $0.4 \mathrm{~m}$ である。地震断層は, 墓地のある小丘の南西を限る低断層崖の中腹や肩に沿って南西 に続き, 市街地の南東端に至る。ここで地震断層は 2 本の断層線に分岐して拉, 主断層から派生する副 断層は緩やかに屈曲しながら北に延びる。分岐地点付近では, 北に傾斜する河岸段丘面を頂部に持つ小丘 が沖積面中に孤立しており，主断層と副断層はそれぞれこの丘の南西縁と東縁に沿って地震変位を生じて いる。分岐地点では, 主要道路が主断層に沿って左ずれ $2.7 \mathrm{~m}$, 東上がり $0.8 \mathrm{~m}$, 副断層に沿って $1.4 \mathrm{~m}$,

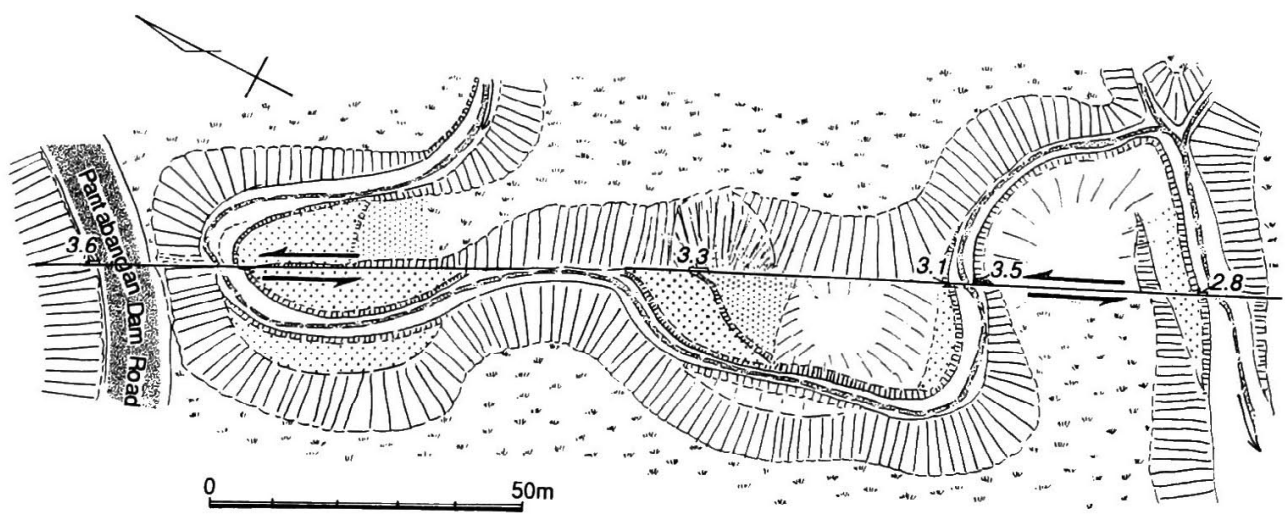

図 8 Pantabangan Dam Road の南の offset stream 中の地震断層変位 左横ずれ変位量 (m) は相対的な隆起側に記入してある。 


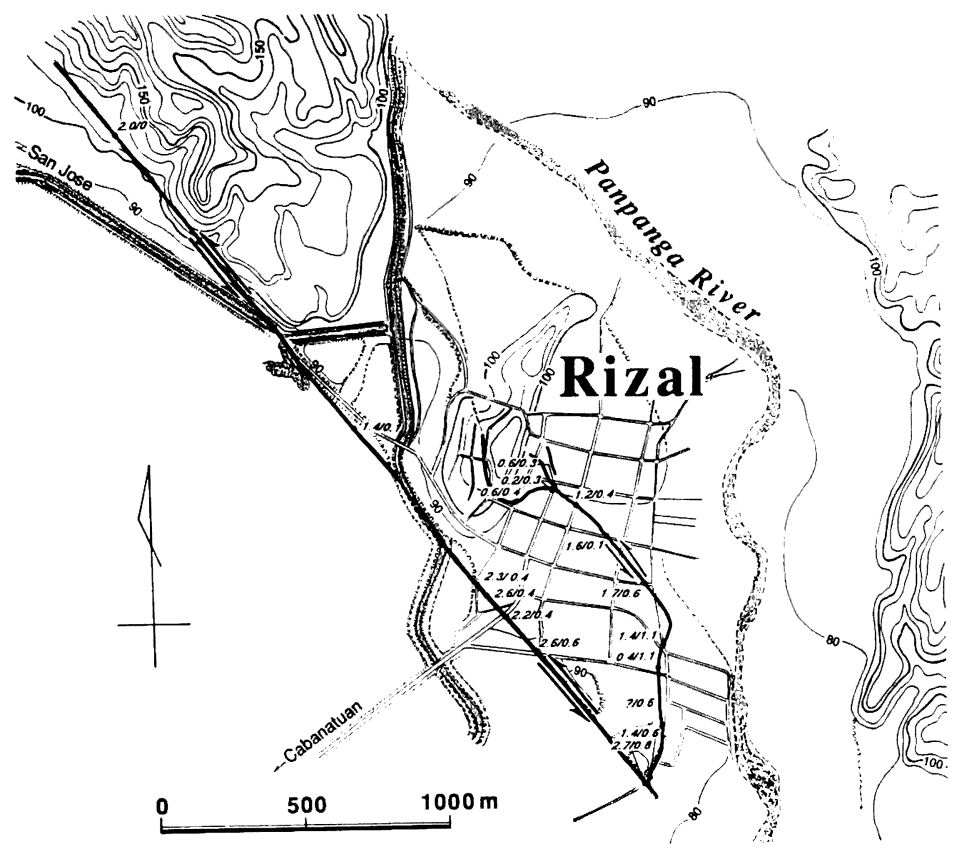

図 9 Rizal 周辺の地震断層

変位量を示す斜め数字は左が横ずれ量 $(\mathrm{m})$, 右は上下変位量 $(\mathrm{m})$ 。数字 は相対的な隆起側に記入してある。

西上がり $0.6 \mathrm{~m}$ 变位しており,これらの断層に摤まれた部分は地疁状に隆起している。北に延びる副断層 に沿っては, 街路が左ずれ $0.4 \mathrm{~m} \sim 1.4 \mathrm{~m}$, 西上がり $1.1 \mathrm{~m}$ の地震变位を受けている。分岐地点から約 600 $\mathrm{m}$ 北で, 副断層は走向を变光, 主断層とほぼ平行して北西に走り街路を最大 $1.7 \mathrm{~m}$ 左横ずれ, 南西上がり $0.6 \mathrm{~m}$ 变位させる。市街地の北の丘陵の東麓でさらに放射状に分岐する。最も南のトレースは，西に向き を变え丘陵頂部を南から回り込むよらに北に続き，丘陵西斜面上に発達する既存の南北方向の逆向き低断 層崖の南端に達する。この低断層崖は, 沖積段丘を切って北に連なるが, これに沿って今回の地震変位が 生じたかどうかは不明である。

市街地南東端より南では, 地震断層は低位段丘上の水田や小径, 段丘崖を変位させ南東に延びる。ここ では, 断層線に沿ってモールトラック状の高まりが発達し，小径や小水路の食い違いから左ずれ $3.6 \mathrm{~m} の$ 変位が認められる。パンパンガ川の右岸の最低位段丘面上にあるコンクリート支柱からなるフェンスの食 い違いは顕著で, $4.6 \mathrm{~m}$ の左ずれ変位が計測された。

7）ボンガボン周辺（図10）

パンパンガ川の左岸では, 地震断層はディグマラ川の沖積扇状地上を $\mathrm{N} 40 \mathrm{~W}$ 走向で南東に延びる。ボ ンガボンの周辺には，北西一南東方向に $600 \mathrm{~m} \sim 800 \mathrm{~m}$ の間隔をもってほぼ平行する 2 本の逆向き低断層崖 が発達しており（NAKATA et al., 1977 ; 平野泳か，1986）, 垂直変位のセンスはリサールより北とは逆 の西上がりとなる。この活断層の一部は ALLEN（1962）によって見いだされ，RUTLAND (1967) によ って Bongabon fault line とよばれたものである。今回の地震では, 西側の活断層に沿って地震断層が出 現した。マカプシンの西で水路や水田の畦の食い違いから左ずれ $1.9 \mathrm{~m}$, 西上がり $0.3 \mathrm{~m}$ 変位が認められ る。マカプシンの集落の南西で道路を横切るところでは，地震断層の走向は $\mathrm{N} 45 \mathrm{~W}$ となり変位は $2.4 \mathrm{~m}$ 左 ずれ，0.6m 南西上がりであった。地震断層は集落の中を斜めに横切り, 断層上の家屋を破壊して南の水 
田に出る。断層の走向は $\mathrm{N} 40 \mathrm{~W}$ となるが断層線の南西には幅 $4.5 \mathrm{~m}$ にわたって N50W の開口割れ目がミの 字状に発達している。断層の沈降側の水田には水が溜り水面が広がっている。マカプシンより南では断層 の沈降側には地震以前に低湿地が認められており，地震変位によってさらにこの状態が助長されている。 地震断層はマカプシンの南で水田の畦や水路を変位させながらバラキャットラルコン (Balacat Larcon)

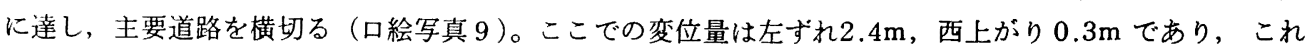
より北のトレースに沿った変位量と大きく違わない。地震断層は既存の低断層崖の基部に沿って南東に続 くが, 横ずれ変位量は増加する傾向を示す。上下変位は概ね西上がり $0.4 \mathrm{~m} \sim 0.6 \mathrm{~m}$ であるが, 多くの場所 で断層を挾んで適当な変位基準が認められなかったり，沈降側が水没したため調査時に正確な量を求める ことができなかった。横ずれ変位量はバラキ+ットラルコンの南約 $1.5 \mathrm{~km}$ の地点で最大となり, 左ずれ量 は $5 \mathrm{~m}$ 前後となる。そこから南に再び変位量は減少し, サントール (Santor)とアンティポーロ (Antipolo) とを結ぶ道路を地震断層が横切る所では, 左ずれ $2.8 \mathrm{~m}$, 西上がり $0.2 \mathrm{~m}$ となる。これより南では地震断層

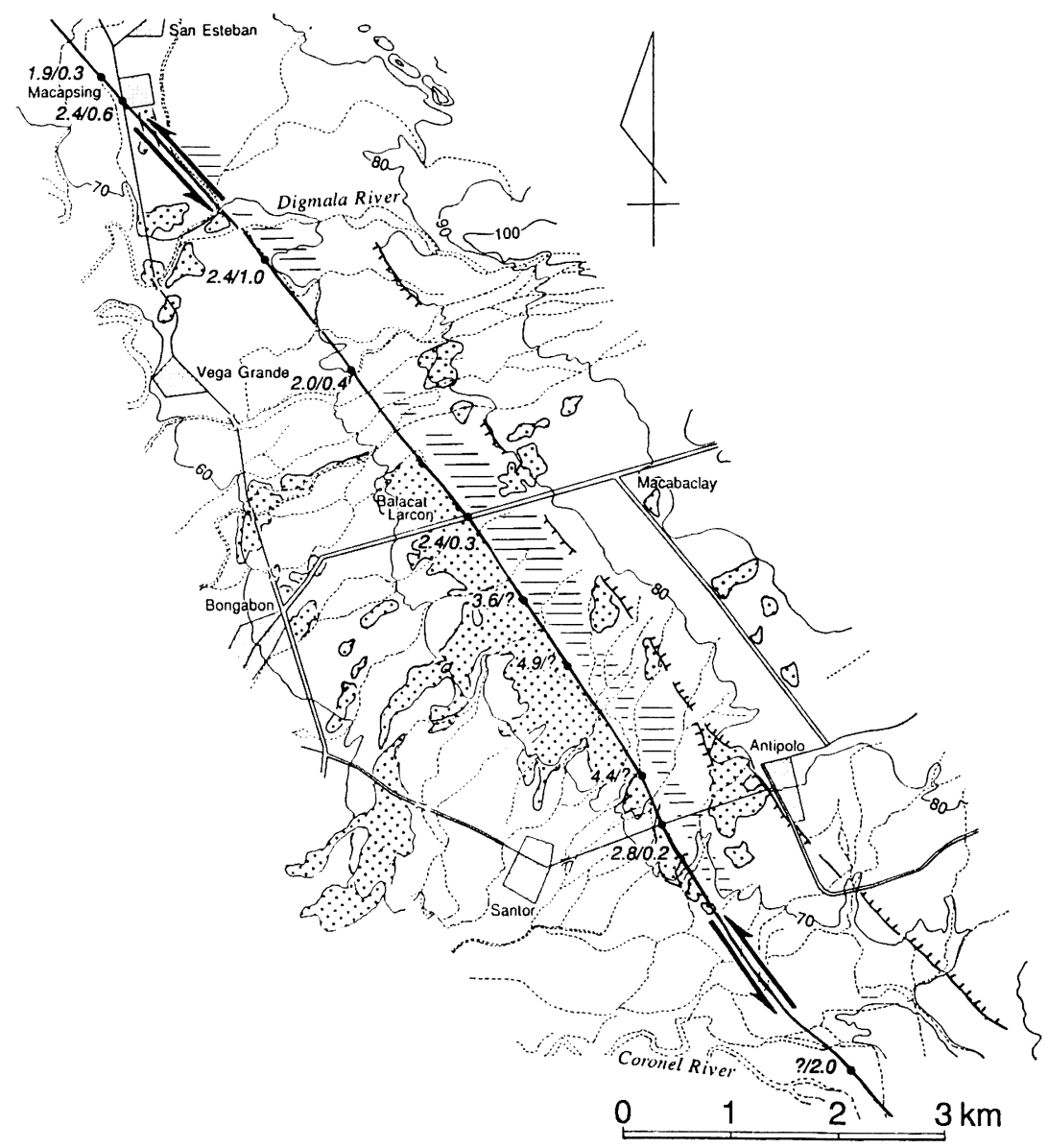

図10 Digmala River の扇状地を横切る地震断層

粗いアミは沖積面中の微高地, 横線は低湿地。ケバ付きの実線は今度の地震では活動し なかった既存の活断層。変位量を示す斜め数字は左が横ずれ量 $(\mathrm{m})$, 右は上下変位量 $(\mathrm{m}) 。$ ? は計測不能あるいは未計測を意味する。数字は相対的な隆起側に記入してある。 


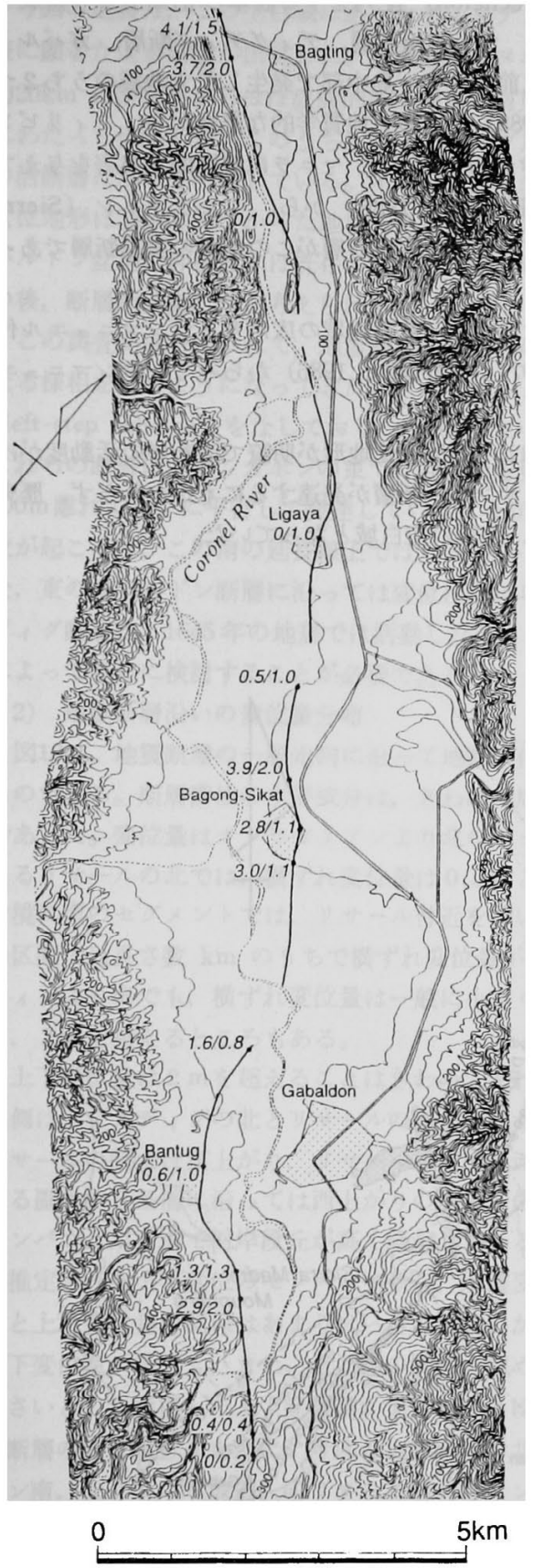

図11 Gabaldon 盆地における地震断層 変位量を示す斜め数字は左が横ずれ量 $(\mathrm{m})$, 右は上下変位量 $(\mathrm{m})$ 。数字は相対的な隆 起側に記入してある。
は引張割れ目が雁行配列をなし，正確な位置が不明で ある。コロネル (Coronel) 川の右岸で西上がり $2.0 \mathrm{~m}$ の地震変位が計測されるが, 横ずれ変位については不 明である。さらに南のラオール (Laur) の対岸では左 横ずれ $2.0 \mathrm{~m}$ が水田の畦のずれから知られるが，さら に南では横ずれ変位量は減少傾向を示す。

8）ガバルドン盆地（図11）

今回の地震で現われた地表断層の南部に位置するこ の地域では, 断層線はガバルドン盆地の注ぼ中央部を 屈曲しながら断続的に南に連なる。地震断層はバグテ ィンの西で道路を横切り, この付近で左ずれ $4.1 \mathrm{~m}$, 東上がり $1.5 \mathrm{~m}$ の上下変位が計測されている。バグテ ィンの南約 $3 \mathrm{~km}$ のコロネル川の右岸に発達する大規 模なプレッシャーリッジの北で, 断層帯の一般方向は N60Wとなる。断層線の走向はさらに西に偏し, 幅30 mにわたってミの字状に雁行配列する開口割れ目とし て認められ, プレッシャーリッジ東縁に達する。開口 割れ目に沿った変位量は, 左ずれ0 0.4m, 西上がり $1.0 \mathrm{~m}$ となり，上下変位成分が卓越するようになる。 これから南, リガヤ (Ligaya) にかけて, 断層線は不 明瞭となるが，リガヤの北で主要道を斜断し，小規模 な地滑りを生じている。リガヤの集落の東半部では, 断層はミの字状に雁行配列する断層よりなる幅 $10 \mathrm{~m} の$ 断層帯をなして，N45Wで南に延びる。集落の南の田 の畦の変位から西上がり $1 \mathrm{~m}$ 前後の地震変位が認めら れる。地震断層はさらに南のバゴンシカット(BagongSikat)の集落の東縁を通って南に延びる。水田の畦や 集落内の小径の食い違いから, 左ずれ $3.9 \mathrm{~m}$, 西上が り $2.0 \mathrm{~m}$ の最大変位が断層線に沿って認められる。バ ゴンシカットとバントゥクの間でも地震断層は大きく N15W方向に屈曲し, 断層線の位置が不明となる所が ある。バントゥクでは集落の東縁をかすめて地震断層 はN75Wの走向で南に続く。集落の南では左ずれ 2.9 $\mathrm{m}$, 西上がり $2.0 \mathrm{~m}$ の最大变位が認められ, 断層運動 のセンスに変化は認められない。これより南では, 盆 地の南西縁に沿って走向 $\mathrm{N} 45 \mathrm{~W} て ゙$ 南東に連なるが, デ ィンガランとの峠付近で, ついに地震断層は認識でき なくなる。地震断層南端での最小計測変位量は西上が ク0.2mである。

\section{IV. 考察}

1）地震断層と既存の活断層との関係 
ルソン島中部では, フィリピン断層は左雁行（left-step echelon）配列をする数本の活断層より構成さ れており, 北西よりサンマニュェル (San Manuel) 断層, サンホセ断層, ディグディグ断層, ガバルド ン断層の 4 つのセグメントに大別できる(図12)。今世紀以前にルンン島中部で発生した大地震のうち $2 つ$ の地震が被害域の広がり（REPETTI, 1946; SEASEE, 1985）と地形・地質学的な証拠から,フィリピン 断層起源の地震と推定される。このうち, 1645年の地震はきわめて大きく, 、ニラに壊隇的な被害を与えて おり, いくつかの地学的証拠（NAKATA et al., 1977; 平野ほか, 1986) から, シェラマドレ (Sierra Madre）山地の南西麓を限るガバルドン断層と, その南方延長部の海底断層がこの地震の震源断層であっ た可能性がきわめて高い。

また，1796年にパンガシナン (Pangasinan) を擎った大地震は, 被害地域の広がりとサンマニュエル付 近の沖積面を切る新鮮な活断層地形（NAKATA et al., 1977；平野ほか，1986）からみて, サンマニュエ 儿断層を震源とするものであった可能性が強い。

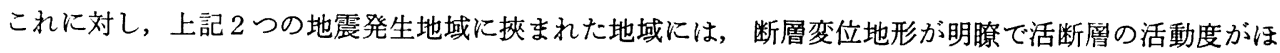
かの活断層々同等であると考兄られるディグディグ断層とサンホセ断層が発達するにもかかわらず，歴史 時代にはこれらの断層を震源とする地震が発生しておらず, 地震の空白域となっていた。

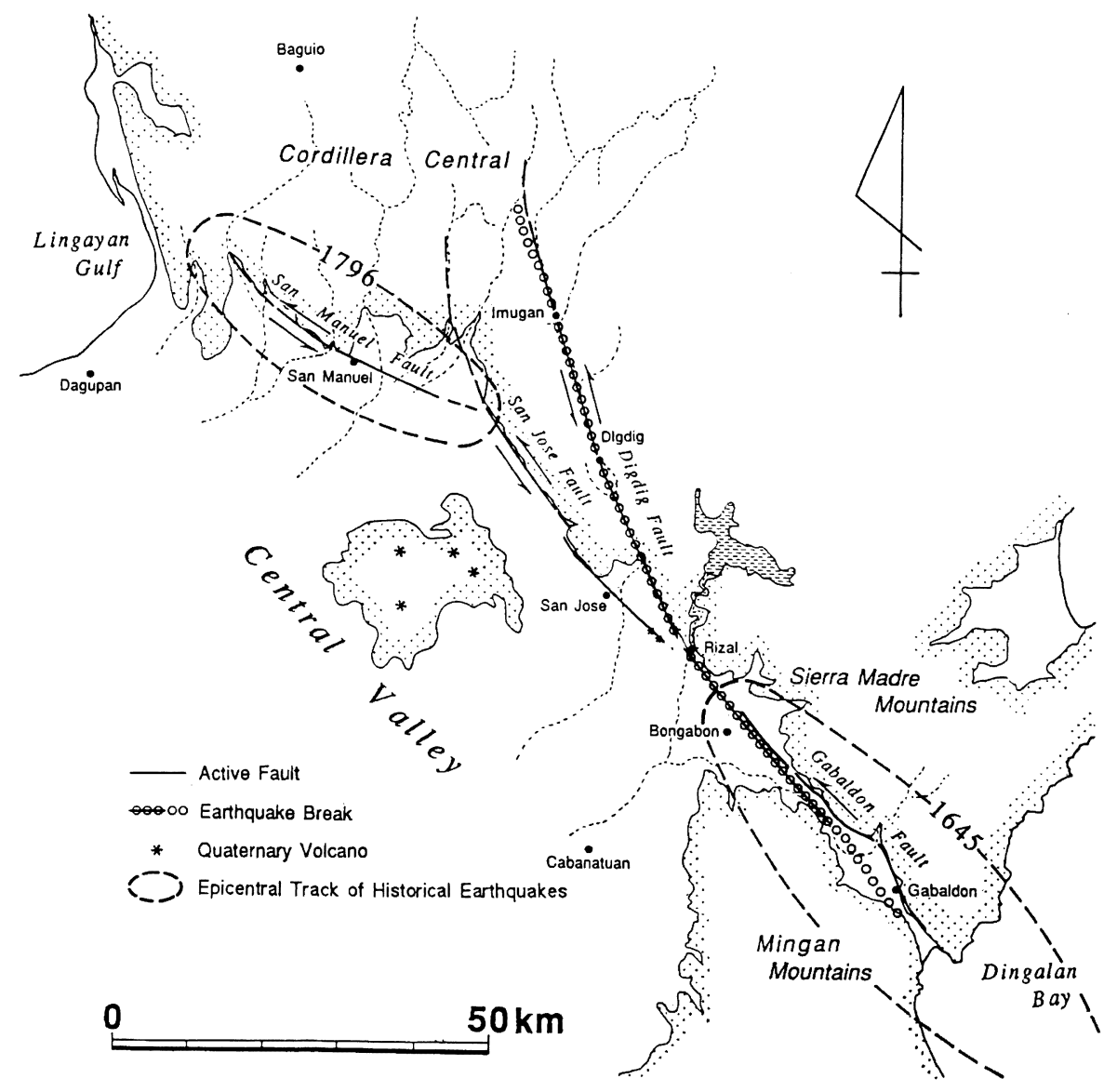

図12地震断層と既存の活断層の関倸 
今回の地震は，この空白域にあったディグディグ断層が活動したため発生したもので，これによって地 表に影著な地震断層が出現した。地震断層はヌェバビスカヤ州サンタフェの西に位置するイムガンの北方 約 $20 \mathrm{~km}$ の断層谷からほぼ直線的に南南東一南東に延び， ヌエバェシハ州バントゥクの南まで約 $120 \mathrm{~km}$ にわたって出現した。このらち, ディグディグ川からボンガボンの南東に至る区間では，地震断層は既存 の活断層に沿って出現している。イムガンより北では直線状谷は認められるが，はっきりした新しい断層 変位地形は認められなかった地域であった。また、コロネル川の右岸の大プレッシャーリッジより南のガ バルドン盆地の沖積面には既存の活断層は認められておらず，この地域は相対的に長い非活動期（静稳期） の後, 断層が活動したと考えられる。

この調査が進むにつれて, 地震断層が私たちの予想に反して南に延び, その地域が1645年の震源域と重 なる様相を示すようになってきた。ディグディグ断層とガバルドン断層はボンガボンの東で左雁行配列 (left-step echelon)をなして拈り，それぞれの断層が独立したセグメントを構成していると考兄られる。 これらの断層は, ボンガボンの東では沖積面を切る低断層崖として地震前から認められており，600m〜 $800 \mathrm{~m}$ 離れて互いに平行して発達している。今回の地震では西侧のディグディグ断層の崖に沿って地表変 位が起こった。この南の延長線上では，ガバルドンの低地に新たに地震断層が現われ，地形的により明瞭 な, 東のガバルドン断層に沿っては変位は認められなかった。したがって，今回の地震を発生したディグ ディグ断層は，1645 年の地震では活動しなかったと推定されるが，これについては今後トレンチ調査など によってさらに検討することが必要である。

2）地震断層沿いの变位量分布

図13は，地震断層の一般走向に沿って地震に伴う断層変位量を，上下成分と横ずれ成分に分けて示した ものである。断層变位の水平成分は，きわめて局地的な副次的断層に沿ら变位を除けば，どこでも左ずれ であった。変位量はナンラガリアンより北のセグメントでは概权 $4 \mathrm{~m}$ 以上と大きい。地震断層が走向を変 えるリサールの北では, 横ずれ変位量は $0.5 \mathrm{~m}$ となり, 上下变位は認められない。横ずれ変位量は, これ を境に南のセグメントでは、リサール付近を除いて， $2 \mathrm{~m} \sim 3 \mathrm{~m}$ と概して小さくなるが，ボンガボンの東 の区間では長さ数 $\mathrm{km}$ のらちで横ずれ変位量が $2 \mathrm{~m} \sim 5 \mathrm{~m}$ と大きく変化するところもある。また，バグ ティンより南でも，横ずれ变位量は一般に小さくなるが，長さ数 $\mathrm{km}$ のセグメントの中央部で大きくな り，3 m を超えるところもある。

上下変位量は $2 \mathrm{~m}$ 超えることはきわめてまれである。変位のセンスは地域によって異なり，相対的隆 起側はディグディグの北とリサールの南で変化する。ディグディグより北では西上がり，ディグディグと リサールの間では東上がり,リサールの南では西上がりのセンスである。ただし、リサールの市街地を横 切る副次的な断層に沿っては西上がりの上下変位が卓越し，断層に㣣まれた地域は隆起域となっており， パンパンガ川右岸で河岸段丘が高く隆起している。これらの上下変位のセンスは，既存の活断層の変位か ら推定される上下変位の七ンスと一致し，地震変位がどこでも累積的であること示している。横ずれ変位 量と上下変位量の関保はあまりはっきりしないが，どちらかといらと，横ずれ変位量が大きいところでは 上下変位量が小さく, また, その逆の関連も認められる。特に, アンティポーロより南の横ずれ変位量の 小さいところで概して上下変位量が大きいことは注目される。

断層の変位量分布を基に, 今回の地震断層を北端から(1)ディグディグ北, (2)ディグディグからサンジュ アン南, (3)サール周辺, (4)リサール南からアンティポーロ, (5)アンティポーロ以南, の 5 つのセグメン トに大きく区分することが可能である。それぞれのセグメントの境界には，断層線の屈曲やギャップがあ り，それぞれが横すれ断層特有の破壊プロセスに関連するものと考兄られるが（SIBSON, 1986 ; KING， 1986 ; 佃, 1990)，この関係を明らかにするにはさらに詳細な野外調査が必要である。

3）地震断層の破壊過程

地震の震央は, 地震断層上に位置するはずであるが, 前述のアメリカ地質調査所の 決めた震央は地震 


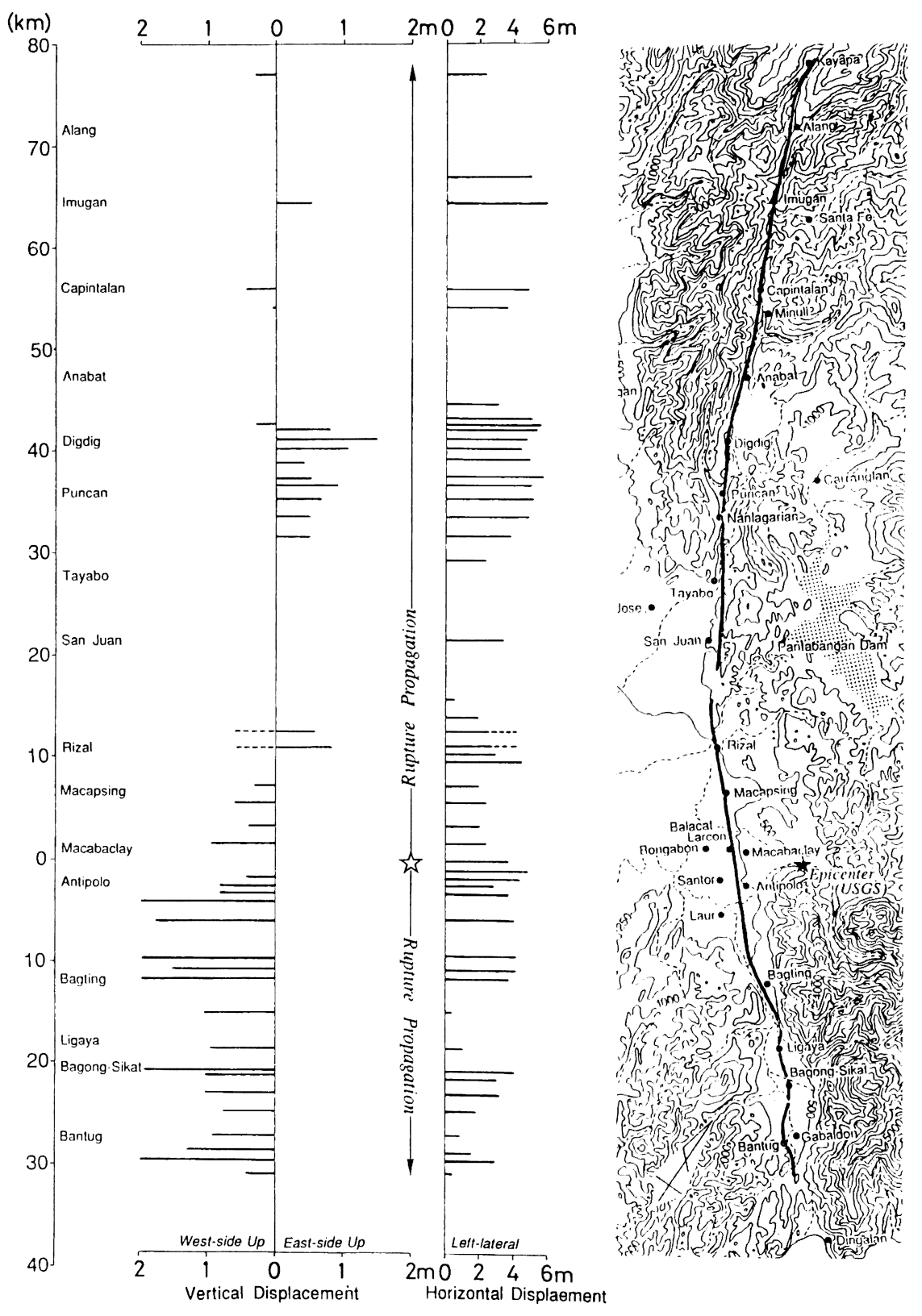

図13 地震断層に沿う変位量分布

黒星印はUSGSによる震央位直。白星印は断層変位から推定した震央位圆。 注意: 垂直変位量は水平変位量の 4 倍のスケールで表現してある。 破線は副次的断扈に沿亏変位量。 

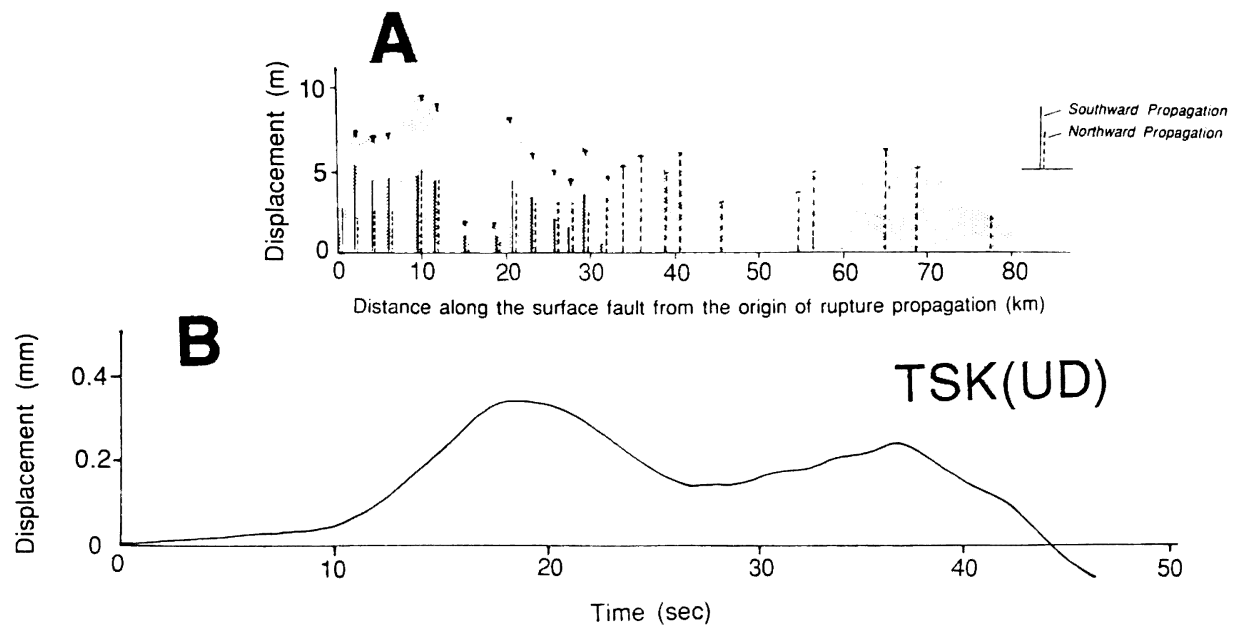

図14 地震断層の変位量から求めた断層変位過程 (A) と震源時間関数 (B)
$\mathrm{A}$ ：震央から等距離にある南北両セグメントの変位量（net slip）の合計を震央からの距離にした がって示した。
$\mathrm{B}$ ：筑波に蒖いた STS 地震計の記録（上下成分変位に值してある）。阿部・吉田（1990）を改変。

断層からかなり離れた位置にある (図13)。横ずれ地震変位を起こした日本の最近の歴史地震の事例では, 断層破壊は一般に圧縮性バリアで始まり，引張性バリアで終息することが多い（佃，1990)。今回の地震で は, 地震学的に決められた震央の近くでは, この種のバリアはリサール付近にある。リサールの市街地の 南東端から北に向かって地震断層が分岐するので, 震央はこれより南東にあったと推定される。従って, 震央位置を USGS が決めた震央に最も近いバラキャットラルコンとアンティポーロの間の地震断層上に 推定することは妥当と考学る(図13)。

地震時の破壊は震央から南北双方向（bilateral） に進行し断層変位が広がり，南への破壊が終息した 後, 北へ一方向（unilateral）に破壊が進行したと推定される。断層破壊は，南北両端の引張性バリアで 終息したと考えられる。余震が断層の北西部に多いことから，北端部の方が南東部より引張性バリアの性 格が強いといえよう。

断層運動は地震波発生に密接に関連している。断層運動のプロセスを調べるために，破壊速度を一定と 仮定して，破壊の広がりと断層のすべり量（変位量）関係を見たのが図 14-Aである。破壊開始地点から の距離は時間に置き換えることができる。この結果は，筑波に置かれた STS 地震計のP 波の初動部分の 記録を上下成分の变位波形に直したグラフ（図14-B：阿部・吉田，1990）の主要動の変動と調和的であ る。すなわち，主要動部分には 2 つのイペントがみられるが，これは破壊の進行に伴う断層変位量の変化 とほぼ対応している。変位波形にみられる初期のゆっくりとした立ち上がりは，最初の10秒間は断層運動 のモーメントが小さかったと考えられている（阿部・吉田，1990）が，この間は深さ $25 \mathrm{~km}$ と推定される 震源から破壊が地表に達するまでにあたる。このように, 地震断層から求められた震源過程は, 地震波形 より推定される震源時間関数をよく説明する。

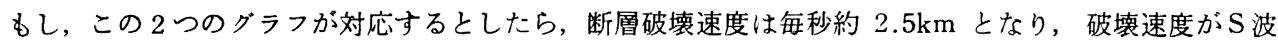
の0.6〜0.7倍とされることと矛盾しない。

\section{V. 結 論}

今回のフィリピン地震の地震断層の特徵は次のようにまとめることができる。 
1）地震は,ルソン島中部のいわゆる地震の空白域に発達する活断層の活動によって発生した。

2）地震断層の出現位置は，既存の活断層のトレースに極めてよく一致しいる。

3）断層の変位様式は, 左横ずれが卓越し，上下変位のセンスは，既存の活断層のセンスと一致してい る。

4）断層変位の量とセンスの急变部は，七グメントの境界部にあたっている。

5）この境界部は, 地震断層の屈曲によって出現した局地的な圧縮域と引張域に一致している。

6）断層の破壊の始まりは，ボンガボンの東の地震断層上に推定された。

7）地震断層の変位量と破壊の払大過程から推定された震源過程は地震波形より推定された震源時間関 数をよく説明する。

\section{VI. おわりに}

今回のフィリピン断層に伴って出現した地震断層は，断層破壊プロセスや活断層の形態的研究に貴重な 資料を提供しており，佃（1990）が指摘するように，これからの活断層研究のために得難い機会を我々 に与えてくれており, さらに詳しい調査が望まれる。本研究には, 平成 2 年度科学研究費総合研究 (A) 「1990年フィリピン地震（M=7.7）の災害に関する調査・研究」（研究代表者 : 安藤雅孝）の一部を使用 した。安藤雅孝氏，阿部勝征氏には現地において有益な議論をしていただいた。記して感謝の意を表す る。

\section{文献}

阿部勝征・吉田康宏 (1990)：1990年フィリピン・ルソン島大地震の発生機構。地霞研究所地震予知観 測情報センター・センターニュース，18，(印刷中).

Acharya, H. K. (1980): Seismic slip on the Philippine fault and its tectonic implications. Geology, 8, 40-42.

Allen, C. R. (1966) : Circum-Pacific faulting in the Philippines-Taiwan region. Jour. Geophys. Res., 67, 4795-4812.

Allen, C. R. (1975) : Geological Criteria for evaluating seismicity. Geol. Soc. Amer. Bull., 86, 1041-1057.

Bonilla, M. G., MARK, R. K. and Lienkaemper, J. J. (1984): Statistical relations among earthquake magnitude, surface rupture length, and surface fault displacement. Bull. Seis. Soc. Am., 74, 2379-2411.

平野信一・中田高・寒川 旭 (1986) : ルソン島中部におけるフィリピン断層の第四紀後期の断層 運動. 地学雄誌, 95, 71-93.

KING, G. C. P. (1986) : Speculations on the geometry of the initiation and termination process of earthquake rupture and its relation to morphology and geological structure. PAGEOPH, 124, 567-585.

NAKATA, T., SANGawa, A. and HiRano, S. (1977): A report on tectonic landforms along the Philippine fault zone in the northern Luzon, Philippines. Sci. Rep. Tohoku Univ. 7 th Ser. (Geogr.), 27, 69-93.

Repetti, W. C. (1946) : Catalogue of Philippine earthquakes, 1589-1899. Bull. Seismo. Soc. Am., 36, 133-322.

RUtLAND, R. W. R. (1967): Preliminary report on the geology of the Laur-Dingalan fault zone, Luzon, Philippines. Report of Investigation, 63, Bureau of Mines, Manila, 1-58.

SEASEE (1985): Series on Seismology, vol. IV Philippines. $843 \mathrm{p}$.

SiBSON, R. H. (1986): Rupture interaction with fault jogs. A. G. U. Monograph, 37(Maurice Ewing 6), 157-167.

佃 栄吉（1990）：地震断層の形態と断層破壊過程. 構造地質, 35, 103-112。

(1990年 9 月 10 日受付, 1990年 9 月23日受理) 